\title{
PUNCHING STRENGTH OF FLAT SLABS WITHOUT SHEAR REINFORCEMENT
}

\author{
Smilja Živković ${ }^{1}$ \\ Martina Vojnić Purčar ${ }^{2}$ \\ Ljiljana Kozarićs
}

UDK: 624.072.1:519.6

DOI: 10.14415/konferencijaGFS2018.004

Summary: The paper presents a short brief of historical development of flat slabs and mechanical models for describing the behavior of the slab around the column exposed to punching. The procedure for calculating the failure load of the of reinforced concrete slabs without the shear reinforcement according to the Eurocode is described in detail, and the numerical calculation was carried out for 11 slabs. The slabs are supported on all four edges, and loaded over centric square column. The variables of these slabs were the strength of the concrete on the pressure and the amount of the longitudinal reinforcement. The obtained results are compared with the existing measured results.

Keywords: flat slab, punching shear, reinforced concrete, Eurocode

\section{INTRODUCTION}

Flat slabs are those which are directly supported on columns without capitals. They can be considered as a good option for concrete buildings since they may reduce the construction time due to the simplification of forms and rebars and especially by attributing greater flexibility in layout of floors. The design of slab-column connection is the most critical point in the design of flat slabs, because of the concentration of shear stresses in this region that can lead to punching, which is a localized failure mode that can occur without signifcant warnings and may lead the whole structure to ruin through the progressive collapse. Figure 1a shows an example of punching failure [1]. One way to ensure local ductility and prevent progressive collapse of flat slabs is through the use of post-punching reinforcement as those shown in Figure 1b, which must be designed to carry the vertical reaction in the column, and must be detailed in order to ensure that they are sufficiently anchored beyond the region of the possible punching cone.

The most significant parameters influencing the punching strength of slabs are primarily the compressive strength of concrete, reinforcement ratio, mechanical characteristics and type of reinforcement used, size and geometry of columns, size effect, and

\footnotetext{
${ }^{1}$ Smilja Živković, dipl.inž. građ., University of Novi Sad, Faculty of Civil Engineering Subotica, Kozaračka 2a, Subotica, Serbia, tel: +381 24554 300, e - mail: zivkovicsmilja@gmail.com

${ }^{2}$ dr Martina Vojnuć Purčar, dipl.inž.građ., University of Novi Sad, Faculty of Civil Engineering Subotica, Kozaračka 2a, Subotica, Serbia, tel: +381 24554 300, e - mail: vojnicmartina@gmail.com

${ }^{3}$ dr Ljiljana Kozarić, dipl.inž.građ., University of Novi Sad, Faculty of Civil Engineering Subotica, Kozaračka 2a, Subotica, Serbia, tel: +381 24554 300, e - mail: kozaricljiljana@gmail.com
} 
Савремена достигнућа у грађевинарству 20. април 2018. Суботица, СРБИЈА

effective depth of the slab. The shear failure of concrete elements without shear reinforcement is directly related to the tensile strength of concrete, which is most often defined as a function of compressive strength. In Eurocode 2, the punching strength is expressed via the function that is proportional to the cube root of the compressive strength of concrete. The reinforcement ratio that is defined as the ratio of the tensile reinforcement area to the effective area of the slab is the parameter that significantly influences punching strength. An increase in the reinforcement ratio also increases the compressive zone, thus reducing the possibility of crack development due to bending, which enables better transfer of transverse forces in the slab-column connection zone [2]. A greater reinforcement ratio also prevents development of tensile cracks, which is favourable for load transfer via the aggregate interlock mechanism. Authors Kinnunen and Nylander changed the reinforcement ratio on slabs $150 \mathrm{~mm}$ in thickness from $0.8 \%$ to $2.1 \%$, and obtained, by reason of this change, a $95 \%$ increase in punching strength. The stress distribution in the slab to column connection also depends on the dimensions and geometry of columns. The stress concentration occurring in the corners of square and rectangular columns logically causes reduction of punching strength compared to columns of circular cross-section.
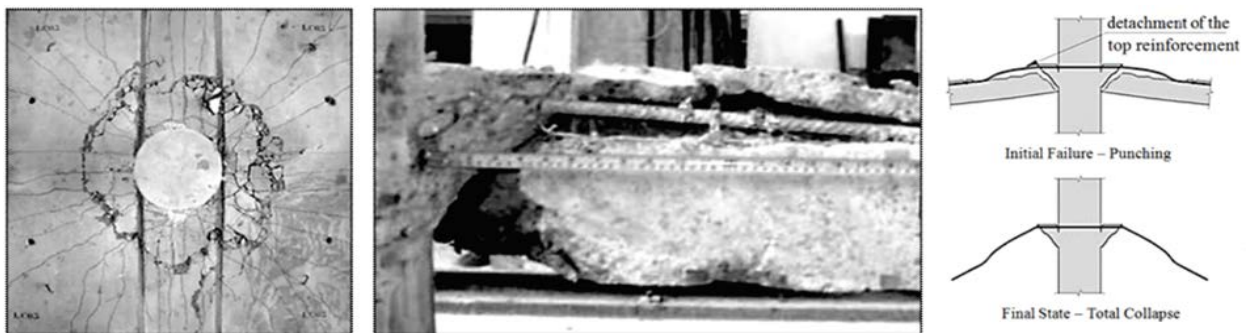

Figure 1. Punching shear failure in slabs without shear reinforcement

\section{HISTORICAL DEVELOPMENT}

At the beginning of the 20th century, almost simultaneously, reinforced concrete slabs were designed and built leaning directly on columns in countries such as Switzerland, Russia and the United States. For this reason, various authors differently interpret the formation of this construction. In the US, engineers George M. Hill, Orlando W. Norcross and C. A. P. Turner are mentioned as the most credited for the development of flat slabs. Gasparini [3] said that the contribution to the development of this system should have been given to George M. Hill, an engineer who designed and built facilities such as filtration plants and warehouses in various regions of the United States between 1899 and 1901. Also, he points out that C.A.P. Turner, an American inventor and engineer, was responsible for demonstrating the reliability of these slabs to numerous built-in buildings. Reed, Schoonees, and Salmond [4], as well as many historical literature, attributed the invention of this construction to the Swiss engineer Robert Maillart, famous for his flat-panel bridges. According to their research, Maillart completed his tests for flat slabs by 1908, for which he obtained the patent in 1909 . Kierdorf [5] points out that this system was developed independently in Russia and that 
Contemporary achievements in civil engineering 20. April 2018. Subotica, SERBIA

engineer Arthur F. Loleit applied slabs without a beam for the first time in Russia in 1907.

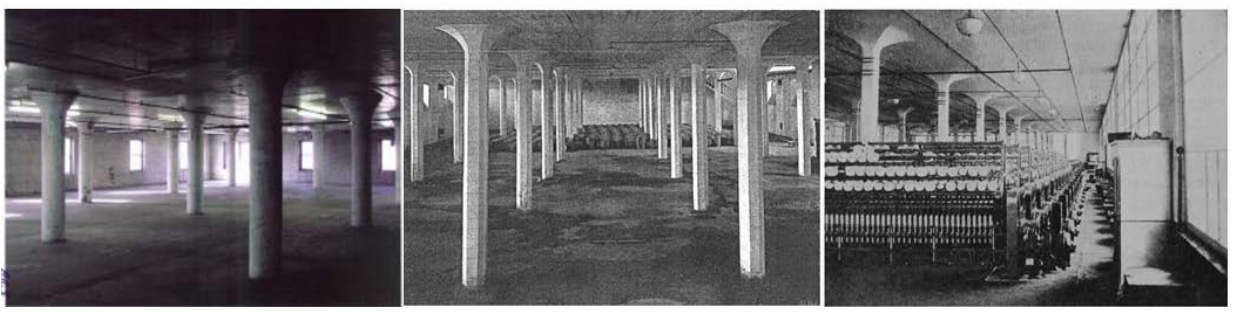

Figure 2. Mushroom constructions: a) Turner, b) Maillart, c) Loleit

Although there were some differences in the quantity and schedule of tensile reinforcement, all the designers, initially, were used the capitals of large dimensions to transfer the force from the slab to the column, and the slabs were not reinforced against punching. The first attempts to reinforce the slabs against punching were the bars of reinforcement bent upwards from the bottom zone, a system that was taken from the reinforcement of the beam to transverse force. Later, other systems of reinforcement against punching were developed, and one of the most commonly used system is headed shear stud system.

\section{MECHANICAL MODELS}

The problem of punching reinforced concrete slabs supported by columns was done by many researchers, and one of the first significant works in this field is the experimental study of Talbot from 1913 [6]. Talbot examined square foundations centrically loaded over square columns and practically, he was the first who introduced a critical crosssection method. The method is based on calculation the nominal shear stress obtained by dividing the load which causes the punching with the surface of the control cross section around the loaded area. Safety against punching is evaluated by comparing this calculated nominal shear stress with the concrete strength parameter, for which the strength of the concrete on tensile or part of it is usually adopted.

However, the thickness of the foundations differed significantly from the thickness of the mezzanine slabs, and for this reason the results of Talbotanis were not adequate in terms of the load capacity of the flat slabs on the punching. In trying to eliminate these and other defects, Elstner and Hognestad tested 39 slabs with varying the strength of the concrete, the percentage of reinforcement, the dimensions of the columns, the way of supporting and loading the slab, and the position and quantity of the reinforcement for receiving the shear force [7].

Due to the ignorance of fracture mechanisms and theoretical methods for determining the relevant forces, the design was performed using empirical expressions and formulas derived from the results of the experimental tests. In 1921 Westergaard and Slater published the first comprehensive theoretical calculation of the internal forces for the slabs without beams. Method of the final differences, they determined the forces in the 
slab, taking into account the different load cases and contributing to the stiffness of the columns and capitals [2].

The American regulations, the ACI Code for the Design of Reinforced Concrete Structures, published in 1925, provides the first recommendations for the design of flat slabs based on experimental research.

In 1960, Swedish researchers Kinnunen and Nylander proposed a mechanical model for describing the behavior of the slab area around the column-support exposed to punching and the procedure for calculating the punching force. For the special case of a radially and tangentially reinforced circular slab, which is supported by a circular column, this proposal well describes the state of stress and strain in the slab at the time of fracture [8]. Regardless of the fact that their theoretical background was developed for slabs that are not reinforced for punching, it serves as a basis for many researchers who have developed models of slabs with a reinforcement against punching.

Today, there are several research groups in the world dealing with the punching phenomenon of slabs with and without the shear reinforcement, of which it is probably the most active research group from the Federal Polytechnic School in Lausanne (Switzerland), led by Professor Muttony. The biggest scientific contribution of this group is certainly related to the new theoretical approach to slab punching, which is based on the critical shear crack theory, $[9,10]$. According to this theory, the punching shear strength of slabs depends on the slab inclination (rotation) due to load, and the slab stiffness defined through bending strength. The theory is based on the assumption that the punching shear strength reduces with an increase in slab inclination, and it has been incorporated in the Model Code 2010.

\section{PUNCHING SHEAR OF SLAB ACCORDING TO EUROCODE 2}

Revision of the boundary load capacity for punching slabs directly supported on columns or loaded with concentrated loads according to Eurocodes [11] is carried out using the critical cross-section method. The shear resistance should be checked at the face of the column and at the basic control perimeter $u_{1}$. If shear reinforcement is required a further perimeter $u_{\text {out,ef }}$ should be found whereshear reinforcement is no longer required. Other control perimeters, $u_{i}$, inside and outside the basic control surface, should be of the same shape as the basic control perimeter. 
Contemporary achievements in civil engineering 20. April 2018. Subotica, SERBIA

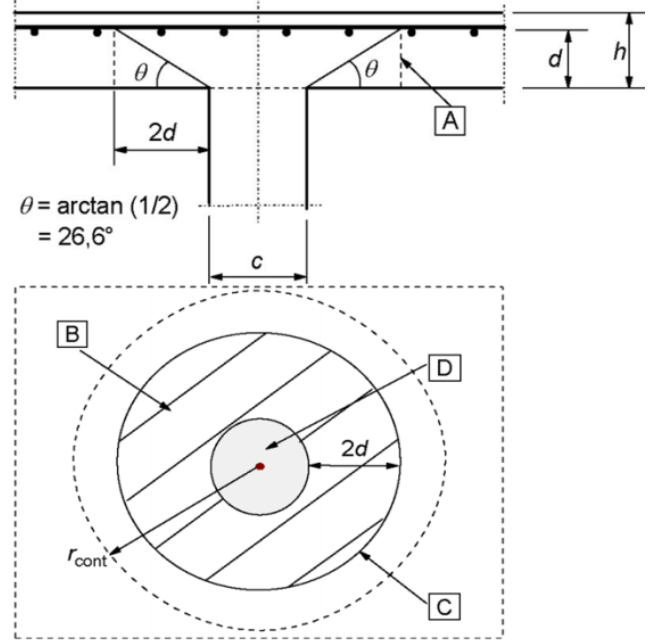

A - basic control section

$\mathrm{B}$ - basic control area

$\mathrm{C}$ - basic control perimeter, $u_{1}$

$\mathrm{D}$ - loaded area, $A_{\text {load }}$

$r_{\text {cont }}$ - further control perimeter

Figure3. Verification model for punching shear at the ultimate limit state

\subsection{Load distribution and basic control perimeter}

The basic control perimeter $u_{1}$ may normally be taken to be at a distance $2 d$ from the loaded area and should be constructed so as to minimise its length (see figure 4).The effective depth of the slab is assumed constant and may normally be taken as:

$d_{e f f}=\frac{\left(d_{y}+d_{z}\right)}{2}$

where $d_{y}$ and $d_{z}$ the effective depths of the reinforcement in two orthogonal directions.
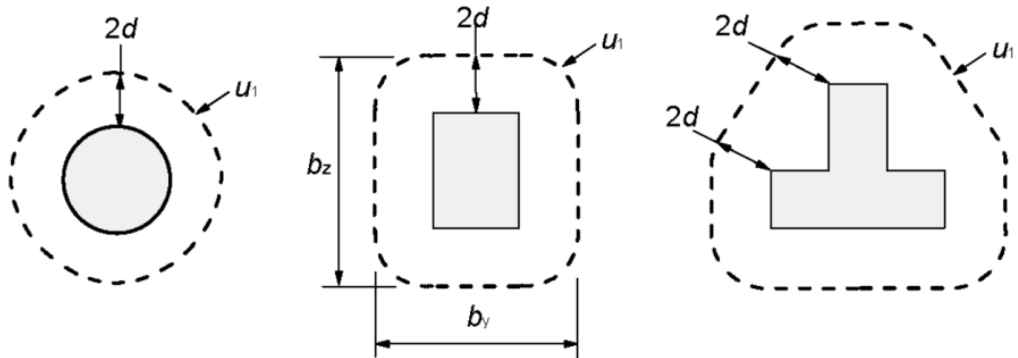

Figure4. Typical basic control perimeters around loaded areas.

\subsection{Punching shear calculation}

The design procedure for punching shear is based on checks at the face of the column and at the basic control perimeter $u_{1}$. Thedesign shear stresses (MPa) along the control sections, are defined as: 


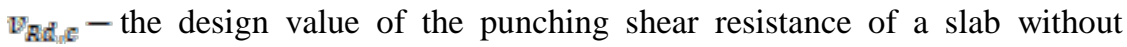
punching shear reinforcement along the control section considered;

$V_{R d c s}$ - the design value of the punching shear resistance of a slab with punching shear reinforcement along the control section considered;

$v_{\text {Rd }} \max$ - the design value of the maximum punching shear resistance along the control section considered.

The following checks should be carried out:

a) At the column perimeter, or the perimeter of the loaded area, the maximum punching shear stress should not be exceeded:

$v_{E d} \leq v_{R d \max }$

b) Punching shear reinforcement is not necessary if:

$v_{R d} \leq v_{R d_{i} e}$

c) Where $v_{E d}$ exceeds the value $v_{R d_{i e}}$ for the control section considered, punching shear reinforcement should be provided according to punching shear resistance of slabs and column bases with shear reinforcement.

\subsection{Punching shear resistance of slabs and column bases without shear reinforcement}

The punching shear resistance of a slabshould be assessed for the basic control section and the design punching shear resistance $M P a$ may be calculated as follows:

$v_{R d_{, c}}=C_{R d, c} k\left(100 \rho_{1} f_{c k}\right)^{1 / a}+k_{1} \sigma_{c p} \geq v_{\min }+k_{1} \sigma_{c p}$

where:

$f_{c k}$ in $\mathrm{MPa}$;

$$
k=1+\sqrt{\frac{200}{d}} \leq 2,0 ; d u m m ;
$$

$\rho_{1}=\sqrt{\rho_{l y} \cdot \rho_{l z}} \leq 0,02$;

$\rho_{l y y} \rho_{i z}$ relate to the bonded tension steel in $y$ - and $z$ - directions respectively. The values $\rho_{i y}$ and $\rho_{i z}$ should be calculated as mean values taking into account a slab width equal to the column width plus $3 d$ each side.

$\sigma_{c p}=\left(\sigma_{c y}+\sigma_{c z}\right) / 2$

where:

$\sigma_{c y^{v}} \sigma_{c z}$ - are the normal concrete stresses in the critical section in $\mathrm{y}$ - and $\mathrm{z}$ directions ( $M P a$, positive if compression):

$$
\sigma_{c y}=\frac{N_{E d y}}{A_{c y}} ; \quad \sigma_{c z}=\frac{N_{E d, z}}{A_{c z}}
$$


Contemporary achievements in civil engineering 20. April 2018. Subotica, SERBIA

$N_{E d, ~} N_{E d, E}$ - the longitudinal forces across the full bay for internal columns and the longitudinal force across the control section for edge columns. The force may be from a load or prestressing action.

$A_{e}$ - the area of concrete according to the definition of $N_{E C}$.

The recommended value for $C_{R d_{c} c}=0,18 / \gamma_{c}, k_{1}=0,1 \mathrm{i} v_{\min }=0,035 k^{3 / 2} \cdot f_{c k}^{\frac{1}{2}}$.

\section{NUMERICAL EXAMPLE}

The calculation values of the fracture force determined on the basis of the EC are compared with the measured values of the fracture force from the work of Elstner and Hognestad [7]. Of the total of 13 slabs of the main series of their examinations, here, it was discussed 11. The slabs were supported on all four edges, and the load was carried out through centric square columns of length of sides $25.4 \mathrm{~cm}$. The variables in this series were the compressive strength of the concrete and the amount of the longitudinal reinforcement. According to Eurocode ratio of reinforcement is limited to $2 \%$, therefore the fracture force obtained according to EC is given in column 7 of Table 1, and the fracture force values obtained using the same terms, but with actual ratio of reinforcement are shown in column 8 of the same table.

The safety coefficients for the loads and properties of the materials are omitted because the load is known during the experiment, and for the used material properties were previously experimentally determined.

Table 1. Measuredt and calculation values of fracture force

\begin{tabular}{|c|c|c|c|c|c|c|c|}
\hline $\begin{array}{l}\dot{\Xi} \\
\text { त्ञ } \\
\text { Шे }\end{array}$ & 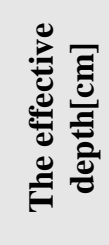 & 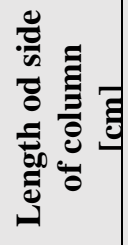 & 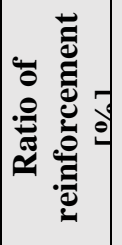 & 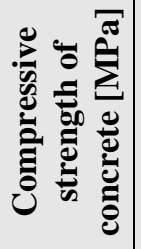 & 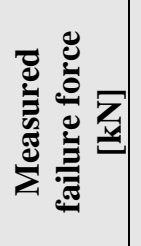 & 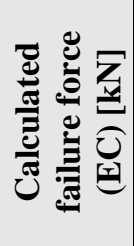 & 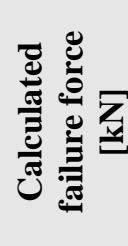 \\
\hline A-1a & 11.76 & & & 14.07 & & & 267.04 \\
\hline A-1b & 1.76 & 25.40 & & 25.23 & 364.75 & & 324.42 \\
\hline A-1c & 11.76 & 25.40 & 1.15 & 29.03 & 355.86 & .95 & 339.95 \\
\hline A-1e & 11.76 & 25.40 & 1.15 & 20.27 & 355.86 & 301.59 & 301.59 \\
\hline A-2a & 11.43 & & 2.47 & & 333.62 & & 325.99 \\
\hline A-2b & 11.43 & 25.40 & 2.47 & 19.51 & 400.34 & 342.26 & 367.21 \\
\hline A-2c & 11.43 & 25.40 & 2.47 & 37.44 & 467.06 & 425.32 & 456.32 \\
\hline A-3a & 11.43 & 25.40 & 3.70 & 12.76 & 355.86 & 297.09 & 364.71 \\
\hline A-3b & 1.43 & 25.40 & 3.70 & 22 & 444.82 & 359.51 & 441.33 \\
\hline A-3c & & & 3.70 & 26.54 & & & 465.55 \\
\hline A-3d & 11.43 & 25.40 & 3.70 & 34.54 & 547.13 & 414.04 & 508.28 \\
\hline
\end{tabular}




\section{CONCLUSIONS}

The calculation of punching of slabs in the regulations of most countries is based on the critical cross-section method. Regulations differ among themselves in terms of determining the position and shape of the critical cross section, the method of calculating the nominal shear stress and the selection of parameters that should represent the strength of the concrete. The paper presents the procedure for calculating the punching shear of reinforced concrete slabs without the shear reinforcement according to Eurocode, and the obtained results are compared with the existing measured results. Even with the omission abovementioned security coefficients for the loads and properties of the material, it has been shown that the real load capacity of slabs was underestimated, especially for slabs having a higher ratio of reinforcement. With neglecting the prescribed limitation of the ratio of reinforcement to $2 \%$, better compliance with the results obtained by the experimental approach would be achieved.

\section{REFERENCES}

[1] P. V. P. Sacramento, M. P. Ferreira , D. R. C. Oliveira , G. S. S. A. Melo : Punching strength of reinforced concrete flat slabs without shear reinforcement. Structures and Materials Journal,2012, vol. 5, № 5, p.p.659-674.

[2] Bartolac,M., Damjanović, D., Duvnjak,I. : Proboj ravnih ploča s posmičnom armaturom i bez takve armature. Građevinar, 2015, vol.67, № 8, p.p.771-786

[3] Gasparini, Dario A.: Contributions of CAP Turner to Development of Reinforced Concrete Flat slabs 1905-1909.Journal of Structural Engineering, 2002, Vol 128, №. 10, p.p. 1243-52.

[4] Reed, P., Schoonees, K., Salmond, J. :Historic concrete structures in New Zealand, Science \& Technical Publishing, Department of Conservation PO Box 10420, The Terrace Wellington 6143, New Zealand.

[5] Kierdorf, A.: Early Mushroom Slab Construction in Switzerland, Russia and the U.S.A. - A Study in Parallel Technological Development, Proceedings of the Second International Congress on Construction History,2006, vol II, p.p. 1793 1807.

[6] Talbot, A. N., : Reinforced Concrete Wall Footings and Column Footings. Engineering Experiment Station, University of Illinois, Urbana, Bulletin No. 67, Mar. 1913, 114p

[7] Elstner, R. C., Hognestad, E., : Shearing Strength of Reinforced Concrete Slabs. Journal of the American Concrete Institute, 1956, Vol. 53, No. 1, p.p. 29-58

[8] Marinković, S.: Granično stanje probijanja armiranobetonskih i prethodno napregnutih ploča. Građevinski kalendar, 2006, Vol. 39, Beograd, p.p.305-351

[9] Muttoni, A., Schwartz, J.: Behaviour of Beams and Punching in Slabs without Shear Reinforcement. IABSE Colloquium, 1991, Vol. 62, pp. 703-708

[10] Muttoni, A.: Punching shear strength of reinforced concrete slabs without transverse reinforcement. ACI Structural Journal105(4), 2008, pp. 440-450.

[11]Evrokod 2 - Projektovanje betonskih konstrukcija - Deo 1-1: Opšta pravila i pravila za zgrade, Institut za standardizaciju Srbije, 2015, Beograd. 
$6^{\text {th }}$

INTERNATIONAL CONFERENCE

Contemporary achievements in civil engineering 20. April 2018. Subotica, SERBIA

\section{ПРОБИЈАҢЕ РАВНИХ ПЛОЧА БЕЗ СМИЧУЋЕ APMATУPE}

Резиме:У раду је дат кратак историјски развој равних плоча и механичких модела за описивање понашања плоче око сртуба изложене пробијању. Поступак прорачуна граничне силе пробијања армиранобетонских плоча без смичуће арматуре према Еворокоду детаљно је описан, а нумерички прорачун спроведен је за 11 плоча. Плоче су ослоњене на све четири ивице, а оптерећене је извршено преко центричних квадратних стубова. Варијабле ових плоча су биле чврстоћа бетона на притисак и количина подужне арматуре. Добијени резултати упоређени су са постојећим мереним резултатима.

Кључнеречи: равне плоче, пробијање, армирани бетон, Еврокод 